\title{
"After Ever After": Social Commentary through a Satiric Disney Parody for the Digital Age
}

\author{
Kylie Schroeder
}

Department of English, Utah State University, Logan, UT 84322, USA; kylie.schroeder@usu.edu

Academic Editor: Claudia Schwabe

Received: 2 April 2016; Accepted: 19 July 2016; Published: 27 July 2016

\begin{abstract}
If you've ever wondered why Disney tales all end in lies," then ask YouTube artist Paint-aka Jon Cozart. He has created a video for YouTube.com that re-imagines what happened after four of Disney's leading ladies' "dreams came true." Continuing a tradition that is as old as the tales he sings about, the artist combines characters and melodies that have become culturally ubiquitous since the media domination of the Disney Corporation with an interpretation of the material that tries to make sense of the world in which it exists. Continuing the criticisms of post-modernism and feminist theory, Cozart challenges the "happily ever afters" that have become the stock endings for the genre. Through comedic satire he creates parodied storylines that bring four animated princesses out of their Disney realms and into the real world where they must deal with environmental destruction, racism, and colonialism, among other issues. The use of a video-sharing site such as Youtube.com not only allows for the expanded distribution of fan-created material, but it also directly addresses a wider audience than traditional oral story tellers could possibly reach: the Internet. This case study looks at the ways in which the global recognition of Disney culture allows for the creation of social commentary through familiar and beloved characters, while an increasingly digitally-connected world impacts the capabilities and understanding of both the creator and the viewers of the material. While far from being a new phenomenon, the reinterpretation of fairy tales takes on content and a form that reflects the increasingly globalized and digitized world in Cozart's Disney parody.
\end{abstract}

Keywords: digital fairy tales; social commentary; Disney; satire; digital storytelling; Cozart; YouTube

\section{Introduction}

"If you ever wonder why Disney tales all end in lies," then you are not alone. In 2013 YouTube artist Paint, named Jon Cozart, created a musical parody that asks this very question and responds with a catchy and humorous but slightly shocking series of answers. The medley was published on the popular video-sharing site, where it has been watched over 61 million times since its publication. The video, titled "After Ever After," reimagines four self-aware Disney princesses (Ariel, Jasmine, Belle, and Pocahontas) in our turbulent reality and explores—or perhaps exposes—the author's version of what has taken place since their "happily ever afters."

This formulaic ending for protagonists of the fairy tale has been pervasive in the genre, especially since the domination of the Walt Disney Corporation began in 1937 with the film Snow White and the Seven Dwarves [1], and as part of children's print literature before that time. The development of postmodernism and feminism in recent decades has resulted in an audience that is less willing to accept that standard and unsatisfying conclusion ${ }^{1}$. Even prior to this criticism, there has been a long history of fairy tale revisions for a variety of reasons. A combination of fairy tale scholarship,

1 For a more extensive discussion see Cristina Bacchilega's work [2,3]. 
new media and amateur media studies, folklore, and cultural studies adds to the analysis of this form of fairy tale revision which reflects the globalized and digitized world in which Cozart's video was created. While there has recently been a surge in fairy tale retellings through television shows, movies, and books to meet this contemporary demand, the unique access and sharing capabilities of YouTube.com allow individuals to create and broadcast their own material to a world-wide audience from the comfort of their own homes. This is the setting in which "After Ever After" has achieved massive popularity. The following case study is one example of the ways in which fan-based material has evolved and is broadcast to its audience.

Cozart parodies the plots of four animated Disney movies with recognizable music from the original films. Not only is this compilation artistic, humorous, and extremely catchy, but it satirically critiques Western society-politics, environmentalism, racism, colonialism, and more-through familiar characters. Cozart's perspective as the creator is that of a young, American male, but his audience is expanded by the content of his parody and the platform through which the material was produced. This case study of Cozart's first "After Ever After" video examines the use of Disney heroines as spokespersons through which Cozart presents a digital parody that also functions as social, historical, political, and environmental commentary. According to noted scholar Jack Zipes, fairy tales "never really end when [they] end" ([4], p. 10) and Cozart is one of many who takes advantage of this and make use of "the end" as a new beginning. In doing so, he retains some aspects of "classic Disney" while subverting much of the sense of wonder that gives the original genre its name. I will review work that has been done in relevant areas of study, present the content of the video, analyze a number of choices made by the author in the creation of the text, and discuss the video as part of the tradition of fairy tale revisions with its role in digital media. Cozart is hardly the first person to create this kind of commentary, but I believe the format and function of the text are worth closer examination.

\section{Literature Review}

This article has drawn from the works of scholars in folklore, media studies, cultural studies, and other disciplines. Each has the potential to inform the others and can be used in combination to build a better understanding of this case study. Fairy tales have permeated many disciplines and have accrued theoretical, literary, feminist, and psychoanalytical analyses stressing social issues such as race and gender representation. From the history and development of the genre to its use in the digital age, fairy tales remain a relevant topic in both academic and vernacular spheres. Scholars have also looked at the way in which commodification has affected those tales and how fans interact with them-especially with the development of technology.

Diverse work has been done in the field of fairy tale studies which focuses on the function of the genre and its relevance - throughout history and in contemporary society. Scholarship has clearly documented the use of folk and fairy tales to respond to the world in which they exist through the evolution of oral tales into print literature and later into diverse forms of media. They have become what Jack Zipes calls a "cultural institution" [4]. In his numerous publications, Zipes has looked at the ways in which the genre has been used and manipulated throughout its history. Along with the analysis of the fairy tale tradition, there has been much critique of the genre. One of the most significant developments in recent years is that of post-modernism and feminism from both scholars and authors within the genre. In Post-Modern Fairy Tales: Gender and Narrative Strategy [3], Cristina Bacchilega provides an analysis of contemporary fairy tale "transformations" through the lens of folklore and literature studies. Bacchilega has also written specifically on feminist fairy tales. Other authors who have explored these theoretical critiques include Kay Stone, Donald Haase, and Marina Warner. These critiques look at the biased and generally patriarchal worldview that is present in the tales, as well as the distrust of the tales' relationship with "truth." Another source of analysis is the commodification of fairy tales, which has perhaps been influenced most by the rise and reign of the Disney Corporation. 
Janet Wasko has focused on the power of the Disney name and its associated products, identifying its unique and recognizable style which is combined with a cultural importance that "cannot be emphasized" enough [5,6]. On a more focused note, scholars such as Kay Stone [7] and England et al. [8] have looked at the role of the Disney princess, while Joel Best and Kathleen S. Lowney inspect the impacts of the Disney reputation for better and for worse [9]. The writings of other scholars including Kristian Moen [10] and Johnson Cheu [11] have also influenced this analysis. While it may seem as though mass production of a fixed text would inhibit the re-tellings of the tales in question, fans have "enthusiastically embrace[d] favored texts and attempt[ed] to integrate media representations into their own social experience" ([12], p. 18).

Henry Jenkins's Textual Poaching, written in 1992, remains applicable in the age of digital culture [12]. Jenkins explores fan culture and the ways in which people interpret and reproduce material that is related to a subject of their interest, from fan fiction to filk (fan folk music). Jenkins writes as both a fan and an academic and looks specifically at the ways in which fans of television shows appropriate material. They "reread them in a fashion that serves different interests" and turn the activity into "a rich and complex participatory culture" ([12], p. 23). While this text was published in the early 1990s, the practices described are still active today, though they have continued to evolve with technology. These fandoms are generated around a shared interest in popular culture, and while Jenkins points out that some of these groups have negative connotations associated with membership, a sense of community is found within the fandom. Jenkins writes that "fans possess not simply borrowed remnants snatched from mass culture, but their own culture built from the semiotic raw materials the media provides ([12], p. 49). Textual Poaching focuses mainly on case studies of fan-composed stories, film compilations, and songs. These forms continue to be relevant in the digital age and their formats have adapted to accommodate the evolving technology.

Since the infiltration of the Internet into daily life-particularly in the Western world-there has been an increase in scholars looking at the impact of the content that appears there. Of particular interest to this study is the work that has been done with "user-generated content," or UGC, especially in the context of amateur-produced media [13]. John Quiggin calls UGC "a distinctive feature of the internet" and the edited work of Hunter et al. examines the social, cultural, and legal perspectives associated with amateur media [13]. This can be seen as a direct extension of the fan-created culture discussed by Jenkins; however, the form, content, and process have been adapted to the 21st century.

Drawing a connection between the former areas of study is a fairly new area of research: digital folklore. In Folklore and the Internet, Trevor J. Blank has combined the work of folklorists pursuing the previously under-studied area of lore that develops in a digital space [14]. He addresses the neglect of scholarship focused on the Internet and the volume provides a variety of topics that highlight the prevalence of folklore in digital spaces. In his introduction, Blank quotes folklorist Alan Dundes: “Technology isn't stamping out folklore; rather, it is becoming a vital factor in the transmission of folklore and it is providing an exciting source of inspiration for the generation of new folklore" [14]. One such digital space that combines user-generated content with fan-interpreted variations of commodified fairy tales is YouTube.com.

\section{Case Study}

The four-minute video entitled "After Ever After-DISNEY Parody" [15] opens to four horizontally arranged frames of the same young man, dressed in four different colored $t$-shirts and standing against four colored backdrops (Figure 1). He is Jon Cozart: YouTube username "Paint." Cozart's channel was created in December 2005 (10 months after YouTube's launch), and in the 10+ years that he has been active, the channel has accrued 3,329,665 subscribers and he has produced over 25 videos. His YouTube channel indicates that "After Ever After" is his most popular video, with over 61,500,000 views in the three years since its publication [15]. 


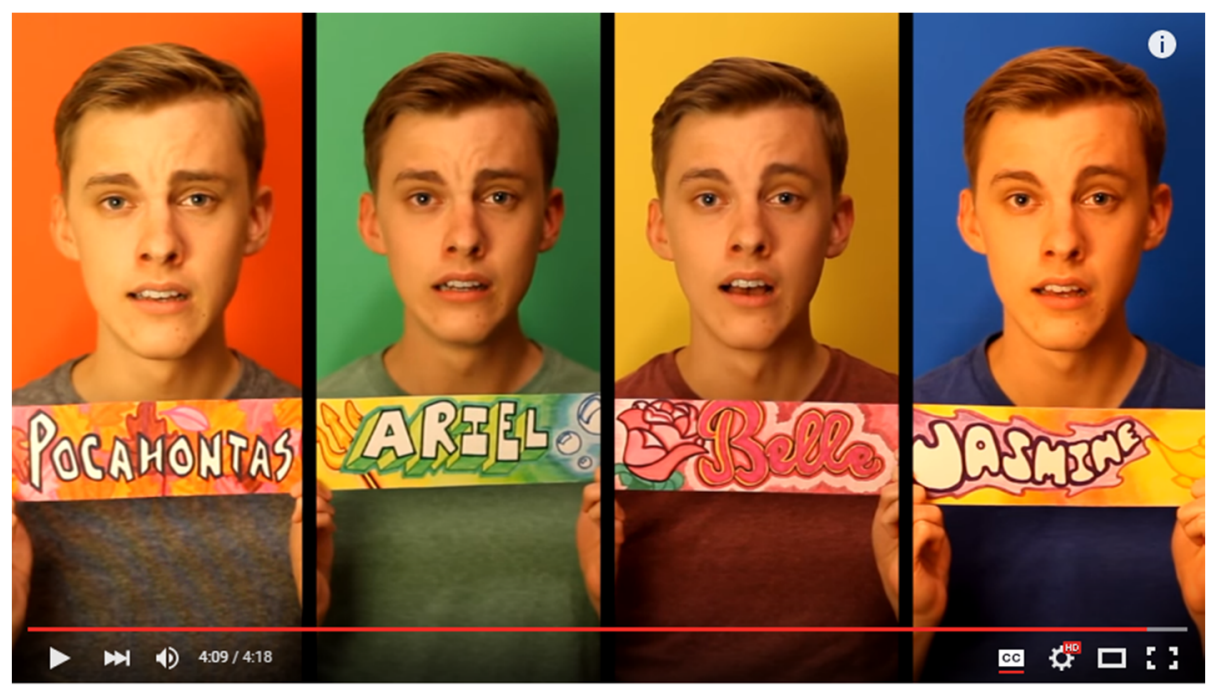

After Ever After - DISNEY Parody

Figure 1. Frames 1-4 from left to right [15].

As the video begins, the Cozart in each frame maintains a fairly passive expression and makes eye contact with the camera. After a moment of silence, all of the Cozarts sing to the tune of "When You Wish Upon a Star" (which is also the melody that accompanies Disney's iconic castle logo before the beginning of the corporation's films): "If you ever wondered why/Disney tales all end in lies/here's what happened after all their dreams came true." This is the first piece of the six-section compilation, and it functions as the introductory narration to the video. Cozart presents a problem that has been noted in scholarship with the rise of feminist theory and post-modernism and offers an explanation as to why-that the "happily ever after" we are given by the classic films is not the truth. The narrators tell their audience that they are about to get a glimpse behind the curtain that Disney lowers at the end of each movie. The speaker then switches from the third person-talking about those with the dreams-to speaking in the first person and takes on the roles of four Disney princesses in order to share their stories.

For the sake of clarity, when discussing the author I will reference Cozart and will the attribute actions of the performer to "Cozart-as" followed by the specific character name. When discussing the words and actions of the fictional character that is speaking, I will use feminine pronouns and the character's name on its own. Finally, when I refer to the background vocalists who are responsible for harmony and secondary characters, I will refer to "Cozarts" in the plural.

The first "ever after" to which the audience is introduced is that of Ariel from the 1989 animated feature film The Little Mermaid [16]. Frame 2 expands slightly and Cozart-as-Ariel holds up a small sign with the princess's name and related imagery (Figure 2). He and his counterparts, who function as vocal back-up and background dancers, sing to the tune of the movie's song "Under the Sea"; however, instead of the original lyrics that celebrate the wonders of living in the ocean, Cozart has parodied the original song with an environmentally-focused theme. 


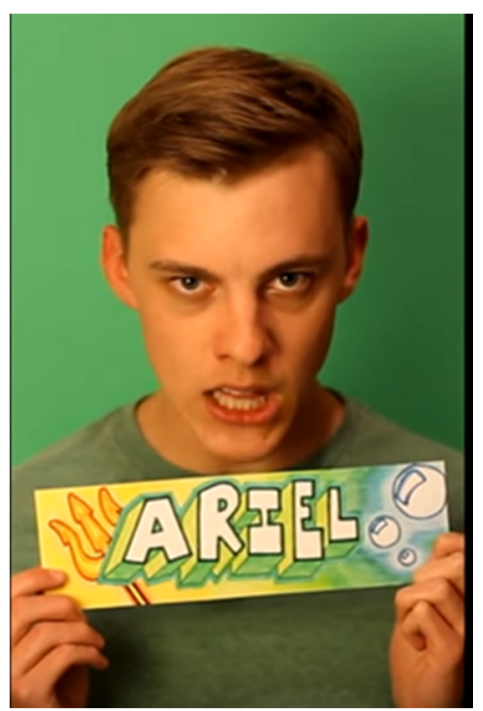

Figure 2. Cozart-as-Ariel. [15]

"I loved being princess down in this beautiful ocean blue/But mermaids are going missing, they end up in someone's stew/So just try to put yourself into somebody else's gills/You're killing my ecosystem with fishing and oil spills/Thank you $\mathrm{BP}^{2}$, thank you $\mathrm{BP} /$ The British are killing, oil is spilling, now I can't see...My Eyes!/Chinamen feast on Flounder's fins/Plus the Japanese killed all my whale friends ${ }^{3} /$ Oceans are browning, I think I'm drowning thanks to BP/You suck!"

Ariel's frame shrinks and the next Princess to sing is Cozart-as-Jasmine from Aladdin (1992) (Figure 3) [17]. She—still Cozart in the first person—shares her fears with the audience to the melody of "Prince Ali".

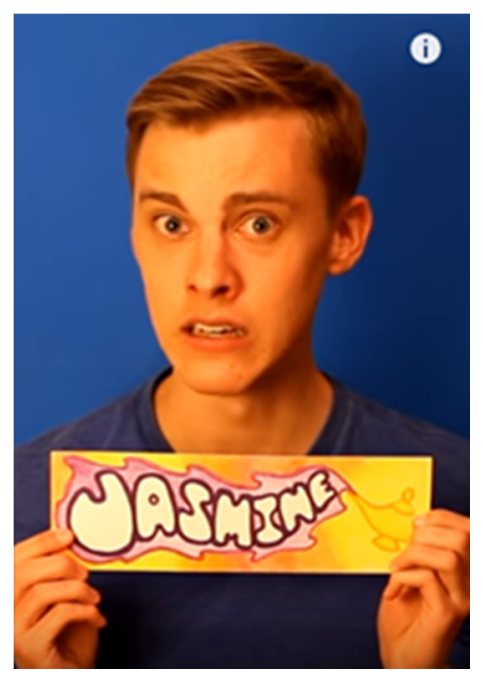

Figure 3. Cozart-as-Jasmine.

2 On 20 April 2012, a drilling rig named Deepwater Horizon exploded and sank into the Gulf of Mexico. It is considered to be the biggest accidental oil spill in history of the industry. At the time of this video's production cleanup was still taking place $[18,19]$.

3 In reference to media outrage against harmful fishing practices. 
"Hey, I'm OK, but I'm slightly scared/My husband's a mark for the War on Terror ${ }^{4}$ / Aladdin was taken by the CIA/We're not Taliban, you've got the wrong man in Guantanamo Bay/Prince Ali, where could he be, drowning in wawa ${ }^{5} /$ Interrogation from the nation of the "free" / Bin Laden's taken the fall, we're not trained pilots at all/Jafar went crazy and no one put up a fuss/We're for freedom, Genie can vouch for us ${ }^{6} /$ Bush was crazy, Obama's lazy, al-Qaeda's not in this country/Set free my Prince Ali!"

Frame 4 diminishes and the third enlarges: Cozart-as-Belle (Beauty and the Beast, 1992) is taunted by the Cozarts in the three minimized frames (Figure 4) [20]. Belle sings to the opening song of the movie ("Belle") and tells the audience:

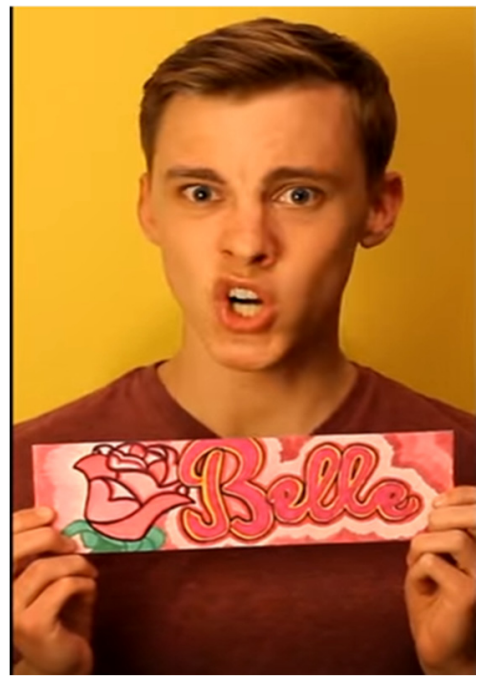

Figure 4. Cozart-as-Belle. [15]

“This town's gone wild since I married Adam ${ }^{7} /$ They think I'm going straight to hell/But the charges laid on me of bestiality/Could wind up getting me thrown in a cell /No, I'm overrun by mad men/I hear they plan to burn me at the stake/They legit believe I'm Satan/And now I hear that PETA's ${ }^{8}$ gonna take my beast away."

The final Disney heroine to contribute to the musical parody is Pocahontas from the 1995 animated feature film of the same name [21]. The original movie ends when her love interest sails away from Virginia. Her song, in the style of "Colors of the Wind," remembers that:

"After John Smith traveled back to England/I helped my people cultivate the fields/More English, French, and Spaniards came to visit/And they greeted us with guns and germs and steel ${ }^{9}$ / They forced us into unknown lands of exile/They pillaged, raped, and left us all for dead/So now I'm far more liberal with a weapon/When I separate their bodies from their heads/Have you ever held the entrails of an English guy? Or bit the beating hearts of Spanish men?/Can you shoot an arrow in some French guy's eyeball? Can you paint with

4 The United States declared an international military campaign called the "War on Terror" after the World Trade Center bombings of 11 September 2001.

In reference to waterboarding.

Expected referential knowledge that Aladdin was responsible for freeing the Genie from his servitude.

The Beast's human name.

People for the Ethical Treatment of Animals.

Guns, Germs, and Steel: The Fates of Human Societies is a 1997 non-fiction book by geographer and physiologist Jared Diamond that won the Pulitzer Prize in 1998 [22]. 
the red colors in these men? / I can murder if I please cause I'm dying of disease/I can paint with the red colors in these men." (Figure 5)

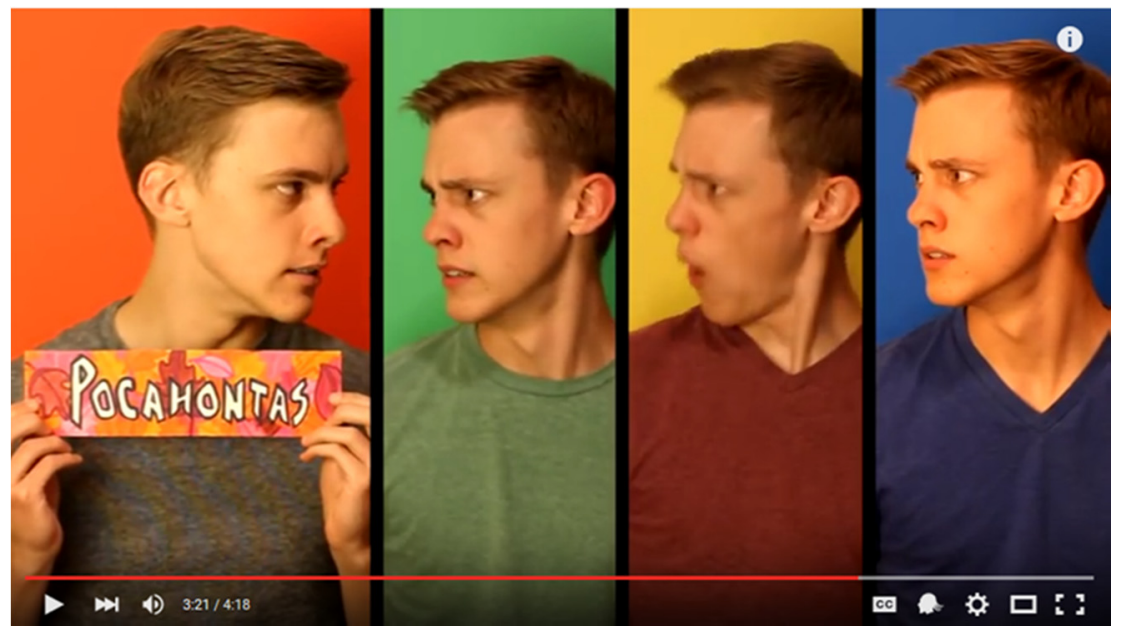

Figure 5. Reaction to Pocahontas' violent solution to colonialism. [15]

The sixth and final piece of the compilation features all four Cozart-as-princesses harmonizing with a thematic phrase from their respective section of the medley. "Thank you BP," mingles with "where's Prince Ali?" "Bestiality" is added by Cozart-as-Belle and finally Cozart-as-Pocahontas chimes in "I've got STDs ${ }^{10}$." The video ends with the six-note melody that accompanies Disney's castle logo at the end of the films' credits. In this way, Cozart's creation is framed by Disney musical rhetoric.

In this case study, there are a number of elements that contribute to the complex construction of the video. In order to discuss the power behind the parody, it is essential to explore the chosen format, content, and characters through which Cozart relates his message. While there are many facets of Cozart's video that would benefit from discussion, this paper will focus on its form and function by examining three choices made by the creator: the format of the "text"11, the question "why Disney (and Disney princesses)," and the use of satirical parody in the case study.

\section{Analysis}

Cozart's "After Ever After" is one of many fairy tale re-writes that have taken place throughout the history of the genre. Jack Zipes states that "[d]uring its inception, the fairy tale distinguished itself ... by both appropriating the oral folk tale [specifically, the wonder tale] and expanding it" ([4], p. 7) Zipes also notes that "the words that are selected in the process of creating the tale allow the speaker/writer freedom to play" with the material in a new way ([4], p. 7). The intention of this analysis is to examine three different aspects of the video that impacted the form and function of Cozart's creation.

While the supplemental information included in the case study was meant to provide context for the parody and the original material, I would like to acknowledge my role as an interpreter of Cozart's work. "After Ever After" is available to anyone with an Internet connection and as such will be seen and understood through an innumerable number of personal experiences. While I have tried to make use of relevant scholarship, my analysis and discussion are influenced by my personal worldview. This being said, I would like to offer possibilities for interpretation-not the singular intended meaning. An interview with Jon Cozart has also shaped my analysis of the material. I want to mention that meaning

10 Sexually transmitted diseases.

11 Used here in the broad sense, referring to the video as a text. 
can be found regardless of authorial intent, and this does not lessen its importance to those for whom the meaning exists.

\subsection{Digital Media as a Storytelling Tool}

Without a doubt, the digital format of this video influences the capabilities of the creator and allows for the production style that is featured in the parody. The genre of online video offers an interesting mix of possibilities that can be compared to oral storytelling and those that are portrayed through mass media (i.e., movies, television, etc.). The web has been a forum for creative expression since its introduction to the public in the 1980s; in Amateur Media, John Quiggen reflects that "ever since the emergence of the internet, those affected by its ever-growing reach have tried to make sense of the new ways of doing things made possible by this technology" ([13], p. 27). YouTube.com is the number one website for user-generated content and its capabilities for free mass distribution allow amateurs to upload content that is widely available to anyone with access to the Internet [13]. In her chapter on the digital salon, Helen Pilinovsky echoes Jenkins in distinguishing between the "original story" and the adaptations that are created for profit [13]. The fan-created medium is separate, though there are some who have crossed the line between amateur and professional activities through their creation of UGC. Other YouTubers that have gone viral with a similar style of production include Todrick Hall, who creates Disney-inspired mash-ups and pop culture music covers, Pentatonix, an a Capella group who have achieved commercial success, and Nick Pitera, known for his one-man music numbers and movie interpretations in which he sings all vocal parts. Cozart's video is a combination of these: he presents an a Capella, Disney-themed, one-man quartet that has been reinterpreted through satire.

The videos themselves are quite intricate, as the digital format allows the artist to create a one-man quartet ${ }^{12}$. "After Ever After" features Jon Cozart, four times over in four separate frames. Not only does he portray the four princesses but he also provides the narration, the background vocals and harmonization, percussive sounds, and additional characters responsible for inserting comments into the songs. These frames, all individually and painstakingly recorded and edited into a single compilation, are choreographed in such a way that the characters seem to be interacting with one another. There is also the additional artistic challenge of recreating the meter, melody, and rhyme of the original songs while altering the content and voice of the characters. Aside from the satiric message that is shared, the video can — and should—be appreciated for its artistry. While a single oral performer can portray different characters and actors in a movie can interact with one another, Cozart mediates between the two through digital media and interacts with himself as he portrays different characters. This is an example of how, through the use of digital media, a single performer is not limited to a solo. In an interview with the artist, Cozart shared that he wanted people to know how much time and effort went into the creation of the final product. Jenkins discusses the drive for "technical perfection" in fan-created work ([12], p. 247) and Cozart clearly reflects this interest.

YouTube as a platform is also an interesting choice for storytelling in a digital format because of its accessibility and prevalence ${ }^{13}$. Not only does it impact the creator's production abilities but it also influences the audience of the video. In an article on digital storytelling as a teaching tool, Dreon, Kerper, and Landis reflect that the "unprecedented access to technology has changed the way ... 'digital natives' communicate, interact, process information and learn" ([23], p. 4). The authors state that "the viral video is the cultural currency of today's youth" ([23], p. 7) and, clearly, Cozart is a practiced money-changer. When asked why he chose the platform of YouTube to share his creations, Cozart responded that "[ $\mathrm{t}$ ] he barrier of entry is so, so low—at least it was when I started making videos 10 years ago. I've always loved the idea of a kid in his room making something for millions of people" [24]. Anyone with access to the Internet is capable of creating a YouTube account, and

12 Variations of this trend are seen elsewhere on YouTube and in popular culture; e.g., Todrick Hall, Nick Pitera.

13 Referring to those with technological capabilities and Internet access. 
an account is not required to view media on the site. As opposed to oral storytelling, YouTube does not provide a live audience or a live performance; however, this does not mean that they are any less interactive. The site allows comments and actions such as voting a clip up or down. "After Ever After" currently has 126,787 comments and a total of 1,243,343 votes (1,226,955 "likes" and 16,388 "dislikes") [15]. When asked about fan response, Cozart stated that while he does not react to negative comments, he "[does] take the audience's time seriously [and] never want[s] to present something that's wasteful of someone's day" [24]. This comment displays a perceived relationship and an accessible venue for audience response and interaction with the text and its creator. Not only does the digital format allow for unique styles of video to be produced, posted, and responded to, but the influence of digital culture has had an impact on globalization and access to current events. This allows Cozart to reference events that are taking place around the world, for people watching around the world. This access to global happenings—or simply the power of a Google search—makes the content of the video relevant and accessible to potential audiences.

\subsection{Why Disney (and Disney Princesses)?}

One of the important aspects of the wonder tale is the identifiable characters who are linked to certain activities, tasks, and settings [25]. In her essay "Some Day My Prince will Come: Female Acculturation through the Fairy Tale", Marcia K. Lieberman states that "[o]nly the best known stories, those that everyone has read or heard, indeed, those that Disney has popularized, have affected masses of children in our culture" (in [26], p. 15) The Disney Corporation has introduced stock characters through the mass commodification of characters in movies, books, songs, and other media. According to Best and Lowney, "[v]irtually all Americans_and much of the world's population-have been exposed to Disney's products" and in the public mind, the Walt Disney Corporation has come to be associated "with decent, family-oriented entertainment" ([9], pp. 445, 433). Not only is the brand perpetuated through films and other media (radio, theater, television, live-action movies), but it is also prevalent in merchandising, educational material, and theme parks. In her analysis of the function of the Disney Princess, Do Rozario states that "Disney's popular image and global profile ... makes the Disney Princess in effect the "princess of all princesses'"' ([27], p. 34). Even when the corporation branched out to produce more mature content under different companies, the "Disney name [was] preserved for animated features ... aimed at children" ([9], p. 436). According to a 2003 article in USA Today, "fairy tales were considered the big-screen domain of Disney animation" in Hollywood [28]. In fact, some scholars suggest that Disney has effectively taken the place of "traditional" fairy tales, as the brand is so pervasive in North America and around the globe [7,9]. The films used by Cozart were all produced between 1989 and 1995, in a period that England et al. refer to as the "middle" Disney princess movies [8] and Do Rozario attributes to "Team Disney," about 20 years after Walt Disney's death [27]. Janet Wasko notes in detail the brand's dominance in the entertainment industry [5,6]: in her book Understanding Disney, Wasko defines the trope of "classic Disney" as closed fantasies with "distinct beginnings and usually happy endings, moral tales, [a] structured story line, light entertainment" along with individualism and optimism, innocence, and the presence of music, humor, and anthropomorphized animals and inanimate objects to move the plot along [5].

Zipes points out in his book The Enchanted Screen: The Unknown History of Fairy Tale Films that there are many filmmakers who have made use of fairy tale material, but is critical of the shadow that Disney casts over other reinterpretations [29]. In some ways, Disney has become canonical when it comes to speaking of fairy tale films, or according to the research of Kay Stone, fairy tales in general [7]. The domination of the fairy tale seems to have created a static representation and general understanding of the fairy tale as it became mass-produced popular culture; however, Cozart's video is a clear example that people are still using fairy tales to deal with issues and are using the digital connections that currently exist to inform and export their retellings. Zipes (among other scholars) takes issue with the ubiquitous nature of Disney culture, and while he definitely makes a point that the tales have been slotted into a Disney form, this case study shows that people are trying to say what they need to say 
with the material that is available to them, and that which will reach a large audience in the case of an artist such as Cozart.

\subsection{The Function of Parody and Satire in "After Ever After" as Social Commentary}

The style of the text-catchy Disney tunes sung with over-animated expression and performed with choreography - is starkly contrasted by the content of the lyrics. In creating this video, Cozart has taken Disney princesses, whose movies are clearly recognized as family friendly, and given the characters distinctly anti-Disney qualities. Instead of being happy with their endings, they react in an angry or concerned way. In the case of Pocahontas, the reaction is one of a violent nature. By removing these women from an idealized fairy tale setting and placing them in our reality, the contrast becomes that much more effective as satiric parody.

Satire and parody are two distinct genres, though they can work together to achieve different purposes. Kreuz and Roberts reference Beckson and Gantz in their definition of satire as "the ridicule of a subject to point out its faults" ([30], p. 100). Likewise, they reference Holman and Harmon in their definition of parody: " . . imitation, intended to ridicule or criticize" ([30], p. 102). When used as a rhetorical device, satire requires knowledge outside of the text and parody is bounded by the text. Cozart's satirical parody assumes that the audience is familiar with not only the Disney movies (plots, characters, songs) but also has a general knowledge of historical and contemporary events. According to Kreuz and Roberts, "[w]hen readers encounter texts, they bring to these works prior knowledge about the text in general. Expectations about the type of text being read are one component of this prior knowledge" ([30], p. 97). The fairy tale is a well-known genre that implies a certain set of actions, and especially in the case of Disney, an expected outcome. Therefore, the use of satire and parody on a genre such as this is able to subvert those expectations through the drastic shift between the known plots of the tales and the lyrics that Cozart has composed, which contain seemingly anti-Disney themes. In an analysis of "fairy-tale collisions" Zipes asserts that "it has become impossible for serious artists to accept the traditional structures and 'goodness' of fairy tales in a globalized world that has gone haywire" ([31], p. 136). The development of UGC with roots in amateur media allows for the visibility of "serious artists" who operate from a non-commercial space.

\section{Discussion}

Without a doubt, "After Ever After" retains many pieces of the tradition that has been commodified and commercialized by Disney. While utilizing these elements, Cozart also creates a medley of anti-wonder tales. Just as the narrator of a fairy-tale can reveal his or her position based on the choices that he or she makes, the material is also left up to the interpretation of the viewer. Oral tales, told face to face, often communicate specific esoteric meanings to the audience. However, the YouTube audience is much broader than that of a traditional oral tale. In a way that is similar to another piece of mass-produced media, there is one original version available. There are restrictions to a deeper understanding of the parody: language, knowledge of current and historical events, and familiarity with the Disney brand. In this audience, individuals are allowed to make different levels of connection within the video and to the world outside of it.

In her book Fairy Tales Transformed? Twenty-First Century Adaptations \& the Politics of Wonder, Cristina Bacchilega discusses artist Dina Goldstein's series Fallen Princesses, in which "[Goldstein] imagines fairy-tale heroines in 'modern day scenarios' and replaces the 'happily ever after'" with hyper-realism [2]. I see Cozart's work expanding on this type of subversion by not only bringing the princesses into the modern world, but by using them as representatives to speak about issues that are larger than themselves through parody and satire. Zipes also mentions Goldstein's work as one of many examples of "fairy tale experimentation" through mediums including photography and painting that he classifies into two categories: "remaking and recreating classic tales" and "conflicted mosaics." The former refers explicitly to widely recognized tales with the intent of offering "startling critique ... that urge[s] ... viewers to rethink what they know about the tales," while the latter 
"draw[s] on an assortment of fairy tale fragments to evoke a sense of wonder" and are "fairy tales unto themselves" ([31], p. 137). "After Ever After" falls into Zipes's first category-though admittedly the tales are canonically Disney-and draws on historic and contemporary "reality" from the worldview of the artist. He is able to reference issues around the globe-from an admittedly Western, if not more specifically American, point of view, while relying on the assumption that his audience will be familiar with both the Disney and the popular culture references, and thereby benefit from the retelling. While Zipes looks at examples of photography, painting, and stained glass among other forms of what might be considered "high art", he does not give much attention to amateur art; he mentions live performance [31], but does not explore examples in detail. However, his conclusions about subversive art are applicable to Cozart's performance: they "unquestionably represent a discontent with the way their actual realities are configured" and reveal "piercing truths of [the artists'] imaginative visions that compel us to re-create traditional narratives and re-think the course our lives have taken" ([31], p. 155).

The three types of satirical commentary in "After Ever After" can be classified as environmental, social, and historical. I have identified these categories based on the main themes that prevailed throughout the video. They are not mutually exclusive and some of the sections feature more than one of the aforementioned genres of commentary. The topics cover a range of issues from pollution and harmful environmental practices to Islamophobia, an unfortunately prevalent theme in today's media and global relations. While Belle's lyrics seem slightly out of context with the social commentary of the other princesses, as they are related to accusations of bestiality and witchcraft, this can be seen as a criticism of the persecution of strong, intelligent women or perhaps the passing of judgement on non-traditional relationships (inter-racial, same-sex) that have been and continue to be a topic of discussion. Again, I would like to stress the influence of personal interpretation, in which the satire suggests an idea-taboo relationships and external judgment-through humor and familiar characters; however, individual viewers are able to assign relevance based on their personal experiences.

In their Disney "happily ever afters," Ariel is transformed into a human and marries Prince Eric while Jasmine chooses to wed Aladdin instead of being forced into an arranged marriage. Belle falls in love with the Beast, which transforms him into Prince Adam. Finally, Pocahontas saves John Smith from harm at the hands of her father, facilitates peace between the invading Englishmen and her tribe, and watches as Smith sails away to Britain. Not only does Cozart disregard these endings, but he uses relevant historic and current events that are connected to the familiar characters. Instead of anonymous (and non-anthropomorphic) sea life being affected by the sinking of the Deepwater Horizon and harmful fishing practices, Ariel's friends are being killed. Cozart's Pocahontas embodies perhaps the most contrary of these plot devices, showcasing her lack of regret in meeting colonization with violence. Kay Stone criticizes Disney for their "portrayal of a cloying fantasy world filled with cute little beings existing among pretty flowers and singing animals" [7] and Cozart's depiction of these princesses is about as far away from their fantasy worlds as they could possibly get. While the video retains enough of the original to make the connection clear-characters, melodies, iconography—he drastically subverts the events they must face. This dissonance can be shocking but it also inspires thought about the issues raised. The satiric setting of the video allows anachronistic connections to be established.

Disney movies have received criticism for the changes that have been made for the commercial value of some of their feature films. Pocahontas, in particular, involved cultural consultants in an attempt to combat this criticism, but the movie is still quite ahistoric in its attempt to fit into classic Disney structure. While Cozart does utilize historic events, the satire is not limited to accuracy. For example, Cozart's Pocahontas reflects the tragedy of colonialism on many American Indian peoples, but uses the stock figure to speak about the experience as it relates to a wider group. Regardless of historical or movie accuracy, the text has been altered to make a maximum impact through its satirical content.

Through the use of recognizable and well-loved Disney heroines, Cozart's dark and satiric but unapologetically catchy parody invites the audience to see the world through the eyes of popular fairy 
tale heroines. These parodied lyrics bring up social and environmental commentary that is currently relevant and would be relevant to the Disney figures if they were inserted into our world. Beloved characters could be dying from pollution or would be discriminated against due to ethnic heritage. While there is definitely a level of shock value in the video, the lyrics also make the audience consider "what if?" the hyper-real situations were true. What if Ariel and Flounder washed up on a beach, dead and covered in black oil slick? Would Princess Jasmine face hate, discrimination, and stereotyping simply because she is an Arab woman? Might Belle be at risk of bodily harm due to the one that she loves? Would Pocahontas resort to blood-fueled rage to deal with the atrocities that resulted from colonization? Are we, as a society, ready to take responsibility for these kinds of consequences? And if it seems horrific through the experience of a fictional character, what is the reality for the populations that the princesses are representing? These are the questions posed through Cozart's satire. These are the thoughts that the satire inspires in "After Ever After" and Jon Cozart uses the medium of digital media to share these ideas through the World Wide Web. Due to the individual and participatory nature of digital media, and the diverse audience to whom access is available, there is not a single or definitive way to interpret the content of the video, but it is open to endless possibilities.

YouTube functions as a digital kind of participatory culture in which interactive action can take place between individuals who have never met face to face. In some respects, this seems like a return to the reinterpretation associated with oral transmission. Quiggen states that as a result of this being a "[c]entral part of everyday life, the dichotomy between participants and observers has broken down" ([13], p. 28). This is facilitated through the comments and voting of the videos, but UGC can also generate another wave of responses. It is interesting to note that there have been several re-makes of Cozart's video since its publication on Youtube.com which have also been posted on the site. These have included a live costumed interpretation while Cozart's voice(s) play over a speaker system [32] and another YouTube user recreated the video with Disney-inspired costumes and her own vocals [33].

\section{Conclusions}

Scholars, authors, and artists have extensively examined historic, postmodern, and feminist fairy tale revisions, but Cozart is pushing the criticism farther through the popular medium of YouTube.com. Compared to early Disney females such as Snow White and Aurora, the characters of Ariel, Jasmine, Belle, and Pocahontas are more autonomous than the first group of princesses: In their films, Ariel and Pocahontas save the lives of their respective love interests. Jasmine and Belle disregard the rules of their societies. Stover claims that this "'new wave' of princess films ... transformed the damsel into a heroine of sorts" ([34], p. 3). Still, they exist within patriarchal societies in which love and a man define their happy ending. Cozart's video explores the contrast between Disney's ideals and the world today in a format that reflects globalization and technological advances in the same way people have reacted to fairy tales since they were more socio-geographically bounded. The take-over of Disney appears to some to have left a mass-produced idea of what a fairy tale should be. This has overshadowed other fairytale interpretations in popular and fringe culture, though more authors are attempting what Zipes calls "de-dizneyfication." Still, Cozart shows through this case study that Disney can be a powerful satiric tool with a wide reach, and uses this to his advantage in the creation of fan-based material. After a period of static fairy tales in pop culture, this video is one example of a re-imagining of the material that is popping up and it is allowed because of globalization. Zipes convincingly argues for the de-dizneyfication of the fairy tale, but one cannot deny its popularity and potential for impact.

A sequel was created by Cozart featuring four new princesses and their various problems in the "real world." It has amassed over 44 million views since its publication in June of 2014. In future work, I would be interested in examining the increasingly proactive nature of the females included in the satire as well as the recent addition of translations of the video and live performances that take place. Clearly, the manipulation of fairy tales has not stopped or been confined solely to that of corporate production: YouTube allows for the creation of user-generated content, increases visibility and participatory culture, and inspires even more re-interpretation. 
Acknowledgments: The author would like to sincerely thank Claudia Schwabe, Lynne McNeill, Lisa Gabbert, Jon Cozart, Geneva Harline, Shannon Branfield, Andrea Blaser, Bethany Hanks, and all those who have contributed to the improvement of this article.

Conflicts of Interest: The author declares no conflict of interest.

\section{References and Notes}

1. Snow White and the Seven Dwarves. Directed by David Hand. Burbank: Walt Disney Productions, 1937.

2. Cristina Bacchilega. Fairy Tales Transformed?: Twenty-First Century Adaptations E the Politics of Wonder. Detroit: Wayne State University Press, 2013.

3. Cristina Bacchilega. Postmodern Fairy Tales. Philadelphia: University of Pennsylvania Press, 1997.

4. Jack Zipes. "The Changing Function of the Fairy Tale." The Lion and the Unicorn 12 (1988): 7-31.

5. Janet Wasko. Understanding Disney: The Manufacture of Fantasy. Cambridge: Polity Press, 2001.

6. Janet Wasko, Mark Phillips, and Eileen R. Meehan, eds. Dazzled by Disney? London: Leicester University Press, 2001.

7. Kay Stone. “Things Walt Disney Never Told Us.” The Journal of American Folklore 88 (1975): 42-50.

8. Dawn Elizabeth England, Lara Descartes, and Melissa A. Collier-Meek. "Gender Role Portrayal and the Disney Princess." Sex Roles 64 (2011): 555-67.

9. Joel Best, and Kathleen S. Lowney. "The Disadvantage of a Good Reputation: Disney as a Target for Social Problems Claims." The Sociological Quarterly 50 (2009): 431-49.

10. Kristian Moen. Film and Fairy Tales: The Birth of Modern Fantasy. London: I.B. Tauris, 2013.

11. Johnson Cheu, ed. Diversity in Disney Films: Critical Essays on Race, Gender, Sexuality and Disability. Jefferson: McFarland, 2013.

12. Henry Jenkins. Textual Poachers: Television Fans and Participatory Culture. New York: Routledge, 1992.

13. Dan Hunter, Ramon Lobato, Megan Richardson, and Julian Thomas, eds. Amateur Media: Social, Cultural and Legal Perspectives. London: Routledge, 2014.

14. Trevor J. Blank, ed. Folklore and the Internet: Vernacular Expression in a Digital World. Logan: Utah State University Press, 2009.

15. Paint. "After Ever After-DISNEY Parody." YouTube, 2013. Available online: https:/ /www.youtube.com/ watch? $\mathrm{v}=$ diU70KshcjA (accessed on 1 April 2016).

16. The Little Mermaid. Directed by Ron Clements and John Musker. Burbank: Walt Disney Feature Animation, 1989.

17. Aladdin. Directed by Ron Clements and John Musker. Burbank: Walt Disney Feature Animation, 1992.

18. Richard Pallarty. “Deepwater Horizon Oil Spill of 2010." Encyclopedia Britannica Online, 2016. Available online: https://www.britannica.com/event/Deepwater-Horizon-oil-spill-of-2010 (accessed on 22 July 2016).

19. BP-United States. “Deepwater Horizon accident and response." 2014. Available online: http://www. bp.com/en_us/bp-us/commitment-to-the-gulf-of-mexico/deepwater-horizon-accident.html (accessed on 22 July 2016).

20. Beauty and the Beast. Directed by Gary Trousdale and Kirk Wise. Burbank: Walt Disney Feature Animation, 1991.

21. Pocahontas. Directed by Mike Gabriel, and Eric Goldberg. Burbank: Walt Disney Feature Animation, 1995.

22. Jared Diamond. Guns, Germs, and Steel: the Fates of Human Societies. New York: W. W. Norton \& Company, Inc., 1997.

23. Oliver Dreon, Richard M. Kerper, and Jon Landis. “Digital Storytelling: A Tool for Teaching and Learning in the YouTube Generation." Middle School Journal 42 (2011): 4-10. [CrossRef]

24. Jon Cozart. Personal communication with author, 15 February 2016.

25. Jack Zipes. Why Fairy Tales Stick: The Evolution and Relevance of a Genre. New York: Routledge, 2006.

26. Jack Zipes. Don't Bet on the Prince: Contemporary Feminist Fairy Tales in North America and England. New York: Routledge, 1987.

27. Rebecca-Anne C. Do Rozario. "The Princess and the Magic Kingdom: Beyond Nostolgia, the Function of the Disney Princess." Women's Studies in Communication 27 (2004): 34-59. [CrossRef]

28. Susan Wloszczyna. "A Fairy-Tale Bending." USA Today, 19 September 2003. Available online: http:// usatoday30.usatoday.com/life/movies/news/2003-09-16-fairytale_x.htm (accessed on 1 February 2016). 
29. Jack Zipes. The Enchanted Screen: The Unknown History of Fairy-Tale Films. New York: Routledge, 2011.

30. Roger J. Kreuz, and Richard M. Roberts. “On Satire and Parody: The Importance of Being Ironic." Metaphor and Symbolic Activity 8 (1993): 97-109. [CrossRef]

31. Jack Zipes. The Irresistible Fairy Tale: The Cultural and Social History of a Genre. Princeton: Princeton University Press, 2012.

32. Victoria Martin. "After Ever After Live at UMass Dartmouth (Better Quality)." Youtube, 2013. Available online: https://www.youtube.com/watch?v=XRYxEhWneSg (accessed on 1 April 2016).

33. Brizzy Voices. "After Ever After (Jon Cozart Disney Cover)." Youtube, 2014. Available online: https: / / www.youtube.com/watch?v=AbHDkOmIB0Q (accessed on 1 April 2016).

34. Cassandra Stover. "Damsels and Heroines: The Conundrum of the Post-Feminist Disney Princess." LUX: $A$ Journal of Transdisciplinary Writing and Research from Claremont Graduate University 2 (2013): 1-10. [CrossRef]

(C) 2016 by the author; licensee MDPI, Basel, Switzerland. This article is an open access article distributed under the terms and conditions of the Creative Commons Attribution (CC-BY) license (http://creativecommons.org/licenses/by/4.0/). 